\title{
The effect of thyme (Thymus caucasicus) ethanol extract on Varroa mite (Varroa destructor), an ectoparasite mite of Apis mellifera meda (Hym: Apidae)
}

\author{
Ataollah Rahimi ${ }^{12^{*}}$, \\ Yaser Khoram Del², \\ Farzad Moradpour ${ }^{2}$ \\ ${ }^{1}$ Department of Plant Protection, \\ College of Agriculture, Razi University, \\ Kermanshah, Iran \\ ${ }^{2}$ Department of Animal Science, \\ College of Agriculture - Kifri, \\ Garmian University, Kalar, \\ As Sulaymaniyah, KRG of Iraq
}

\begin{abstract}
Chemical control of the Varroa mite (Varroa destructor), which is one of the most important pests of honey bees, is practiced on a worldwide scale. However, because of abundant use of different acaricides, the mites have become resistant to many of them. We chose to apply non-synthetic chemicals for control of Varroa mites by using thyme (Thymus caucasicus) ethanol extract on honey bees. In September-October 2013, we collected wild thyme growing in Kurdistan mountains, ground it, and its ethanol extract was made by using $95 \%$ ethylic alcohol. We used a randomized complete design with ten treatments of different concentrations of ethanol extract of thyme as a statistical model and one control with pure $95 \%$ ethanol with four replications. The interior temperature of the brood chamber was measured to be $30 \pm 1^{\circ} \mathrm{C}$, and the ambient temperature surrounding them was $33 \pm 2^{\circ} \mathrm{C}$. We sprayed the extracted thyme solution on honey bees and counted the number of dead mites by picking them out from the bottom board of each hive at every $12 \mathrm{~h}, 24 \mathrm{~h}$, and $48 \mathrm{~h}$ intervals after spraying. The results showed that the use of the thyme extract influenced significantly the percentage of mortality of dead mites in the extract-sprayed treatment and the control treatment. The percentage of mortality of the honey bees in control hives and the honey bees treated by thyme ethanol extract did not have a significant difference. Results of our experiment using ethanol extract of thyme showed that its use in hives was safe without a high risk of mortality for honey bees.
\end{abstract}

Keywords: Honey bee, Iran, Kurdistan province, thyme extract, Varroa mite

\section{INTRODUCTION}

The Varroa mite (Varroa destructor) (Anderson \& Trueman, 2000) is one of the most impor-

*Corresponding author: E-mail: rahimi.ata.1@gmail.com tant pests of the European honey bee (Apis mellifera L.) and the most threatening agent of its colonies throughout the world (Anderson, Trueman, 2000). The mites spend their developing stages in the pupa cells of honey bees which causes an irreparable damage to bee colonies. By sucking 
the hemolymph of pupae and adult honey bees, the Varroa mites reduce the water content and the total body weight thus lowering the protein and carbohydrate content and finally causing the death of the bees (Bowen-Walker, Gunn, 2001; Rahimi et al., 2014). In addition to direct damage, the mite, which is an ectoparasite, transfers entomopathogens such as viruses, thus causing malformation of body parts and a reduction of life span of workers and drone bees in bee colonies (De Jong et al., 1982). Different pyrethroid acaricides such as Flumethrin, Neo-Fluvalinate have been used in honey bee hives for control of Varroa mites in recent years but their use has caused different side effects such as the presence of residue in what any honey bee hive could produce, contamination of the environment and enhancing of the resistance of mites to these acaricides (Milani, 1995; Elzen et al., 1998; Raja et al., 2001). Nowadays researchers tend to find safer methods to control Varroa mites. One of these methods consists of using plant extracts. Secondary metabolites of some of the plants have an important role to play in withstanding pest damages, so the use of these plant derivatives could replace chemical acaricides in the control of mites (Kim et al., 2005; Ghasemi et al., 2010). In addition, when compared with chemical pesticides, plant extracts are more compatible with ecosystems, less toxic to mammals and non-target organisms, and leave no persisting materials in nature (Georges et al., 2007; Liu et al., 2005). In the USA, Australia, and India numerous studies were conducted on the use of extracts of pyrethrum and azadirachtin and these extracts proved to be highly toxic on stored products (Levinson, Levinson, 1998). Plants of the Meliaceae family were studied to find extracts that could play the role of repellents, antifeedants or insect growth regulators (Reed et al., 1982). Extracts of the Buckthorn (Melia azedarach) Elaeagnaceae, Peganum harmala L. Nitrariaceae, wild marjoram or oregano (Origanum vulgare L.) Labiatae, thyme (Thymus vulgaris), Lamiaceae, China berry (Melia azedarach) Meliaceae were studied to identify their insecticide effects on insects such as the red flour beetle (Tribolium castaneum) (Col: Tenebrionidae) and Noctuid leaf eater larvae (Spodoptera exigua), and to evaluate the antifeedant properties of those extracts on the Colorado potato beetle (Leptinotarsa decemlineata), aphids (Homoptera: Aphididae), and whiteflies (Homoptera: Aleurodidae) (Ventura, Ito, 2000; Szczepanik et al., 2012; Yazdani et al., 2014). Thymol, as one of the essential oils extracted from thyme, proved to play the role of the GABA (Gamma-aminobutyric acid) mimeting and modulating agent. GABA is a neurotransmitter that exhibits both excitatory and inhibitory actions in insects, mediates muscle activation at synapses, and stimulates certain glands (Priestley et al., 2003).

Thyme (Thymus caucasicus) is a roughage perennial plant of the Lamiaceae family that originated from the Mediterranean region. Its height is $20-50 \mathrm{~cm}$, the leaves are small, opposite, styliform, calyx 3-4 mm, with short hairs, the tube is campanulate, has small flowers in white pink or violet colours that appear as assembly at the top of stems exiting on sides of leaves with a 1-mm dark brown achene fruit with four seeds inside. The plant contains 1-2\% of essential oil that is yellow in colour and is composed of thymol, carvacrol, tanins, flavonoids, saponins, and substances with a bitter taste. Although up until now thyme has been mostly used for its pharmaceutical qualities and as a medicinal plant, now there is evidence that it should be also used as an acaricide and an insecticide. However, more studies are needed to confirm such properties (Ghasemi et al., 2010; Wandscheer et al., 2004; Akbarinia, Mirza, 2008). Beekeepers can monthly do one practice to manage Varroa mites in their colonies using mechanical methods (e.g., sprinkling honey bees with sugar syrup). In our study, we studied the effect of thyme leaf extract on adult Varroa mites and the possibility of using this extract to control this mite.

The objective of this study was to evaluate the effectiveness of thyme ethanol solution on honey bees infected with Varroa mites and to find out if its use could cause any undesirable or negative effects on honey bees by comparing mortality of the bees sprayed with thyme extract with that of the control bees. 


\section{MATERIALS AND METHODS}

Our study was conducted during September-October 2013 using honey bee colonies in Saqqez city in Kurdistan province, Iran. We used the statistical method of Randomised Complete Design (RCD). We carried out ten treatments and four replications for every treatment. Ten treatments were sprayed with thyme ethanol extract, one treatment considered as control was sprayed with pure ethanol. The data were analysed using IBM SPSS v. 22, the graphs were drawn by Excel.

\section{Extraction procedure}

The mountain-growing thyme was collected from its natural growing soils in the Kurdistan Province during August-September of 2013. After transfer to laboratory the plants were dried in shade under dry conditions. An electrical grinder (Moulinex ${ }^{\oplus}$ France) was used to grind the collected materials entirely: the grinding was done for 8 minutes, 95\% ethanol was used for extraction, for doing the job, 60 grams of powdered Thyme was put in a $500 \mathrm{ml}$ Erlenmeyer flask, enough quantity of ethanol was poured on it and the volume was brought to $100 \mathrm{ml}$. We used a fume hood (Adaco Co. Tehran) to stir the mixture thoroughly, then we covered the flask completely with an aluminium sheet to prevent direct exposure to sunlight. The mixture was laid in a refrigerator for $24 \mathrm{~h}$ at $+5^{\circ} \mathrm{C}$, after which we used filter paper to separate the plant extract from the plant tissues. The process of extraction was repeated for a second time by pouring $10 \mathrm{ml}$ of ethanol into the flask. The flask was shaken thoroughly for one hour using an electric shaker, rotator and mixer, 2000 (Labtron Co. Tehran), and the extraction was repeated once again. The extracted mixture was poured into a $15-\mathrm{mm}$ Petri dish and evaporation of the solvent was made possible by leaving it under the fume hood for 24 hours, after which a $10-\mathrm{ml}$ volume of raw dense extract was obtained (Dehghani, Ahmad, 2011).

\section{Bioassay}

Bioassay was done following Ruffinengo et al., 2005, with minor modifications. Our study was concentrated on the effect of the ethanol extract of wild thyme on adult Varroa mites. Each experimental unit consisted of one honey bee hive with eight honey bee frames. The adult mites were present on the bodies of the bees, on the frames and on the open door cells. In every replication we sprayed all of the eight frames and both sides of each of the frames, the walls and the floor of the hive with thyme ethanol extract. Prior to the spraying, a white board was inserted on the bottom of each of the studied hives. After 12, 24, and 48 hours following the spraying all the frames were shaken over the white board and the dead mites were counted. The death of mites was verified by irritating them with a small hair brush: the mites without movement were considered dead.

\section{Determination of the $50 \%$ mortality con- centration $\left(\mathrm{LC}_{50} \%\right)$}

To study the $\mathrm{LC}_{50}$ of thyme ethanol extract, different treatments of different concentrations of the extract $(5-90 \mu \mathrm{L} / \mathrm{ml})$ were carried out and the correction was made for the percentage of mortality to 40 mites (Table 1 ). The $\mathrm{LC}_{50}$ was calculated using probit analysis.

Table $1 . \mathbf{L C}_{50}$ of thyme ethanol extract on Varroa mites 24 hours after spraying.

(Corrected percentage of mortality of Varroa mites 24 hours after spraying (CPMV24 h))

\begin{tabular}{c|c|c}
\hline $\begin{array}{c}\text { Concentration } \\
(\mu \mathrm{l} / \mathrm{ml})\end{array}$ & $\begin{array}{c}\text { Number } \\
\text { of mites }\end{array}$ & $($ CPMV24 h) \\
\hline 5 & 40 & $27.28 \pm 3$ \\
\hline 10 & 40 & $51.1 \pm 3.1$ \\
\hline 20 & 40 & $51.3 \pm 2.8$ \\
\hline 30 & 40 & $66.5 \pm 3.2$ \\
\hline 40 & 40 & $79 \pm 3.3$ \\
\hline 50 & 40 & $96 \pm 3.01$ \\
\hline 60 & 40 & $80 \pm 3.2$ \\
\hline 70 & 40 & $97 \pm 2.1$ \\
\hline 80 & 40 & $98 \pm 3.07$ \\
\hline 90 & 40 & $100 \pm 3.8$ \\
\hline & LC $_{50}$ & 12.6 \\
\hline
\end{tabular}




\section{Data analysis}

StatPlus v. 4.9 was used and analysis of variance was done by the one-way ANOVA method. The comparison of the means was done using Tukey's HSD Test, with 5\% error level. If there were any mites observed dead in control treatments, the Abbott formula was used to correct the percentage of the dead mites in other experimental treatments. The $\mathrm{LC}_{50}$ was measured by using StatPlus v. 4.9 and probit analysis.

\section{RESULTS}

The results showed that by using a $50 \mu \mathrm{L} / \mathrm{ml}$ of thyme extract the mortality rate was $55 \%$ after 12 hours of spraying, while in the control treatment it was only $12 \%$ and there was a significant difference between the mean of dead mites counted in the treatment in which the concentration of the extract was $50 \mu \mathrm{L} /$ $\mathrm{ml}$ and the control treatment $(P \leq 0.05)$. After 24 hours of spraying the mean number of dead mites reached $67 \%$ in the same concentration of thyme extract while it was $16 \%$ in the control treatment; finally, after 48 hours of spraying the mortality rate of the sprayed mites was $72 \%$, while in the control treatment the mortality percentage was $18 \%$. Again, there was a significant difference between the percentage of dead mites in the extractsprayed treatment and the control treatment (Fig. 1) $(P \leq 0.05)$.

Simultaneously, at the end of each count for every treatment and replication, the number of dead honey bees found at the bottom board of each hive was counted. The mortality of bees in different treatments in which the thyme extract was used 12, 24, and 48 hours after the application of the extract were $13 \%, 14 \%$, and $16 \%$ respectively, while in control treatments the mortality of the bees were $11 \%, 12 \%$ and $14 \%$, respectively, after the same numbers of hours. When compared, there was no significant difference between the percentage of mortality of bees in treatments in which thyme extract was used with the control treatment (Fig. 2).

The results obtained showed that the $\mathrm{LC}_{50}$ mortality of the Thyme extract for adult Varroa mites was $12.6 \mu \mathrm{l} / \mathrm{ml}$ and this study convinced us that the ethanol extract of thyme could effectively control Varroa mites in honey bee hives (Table 1).

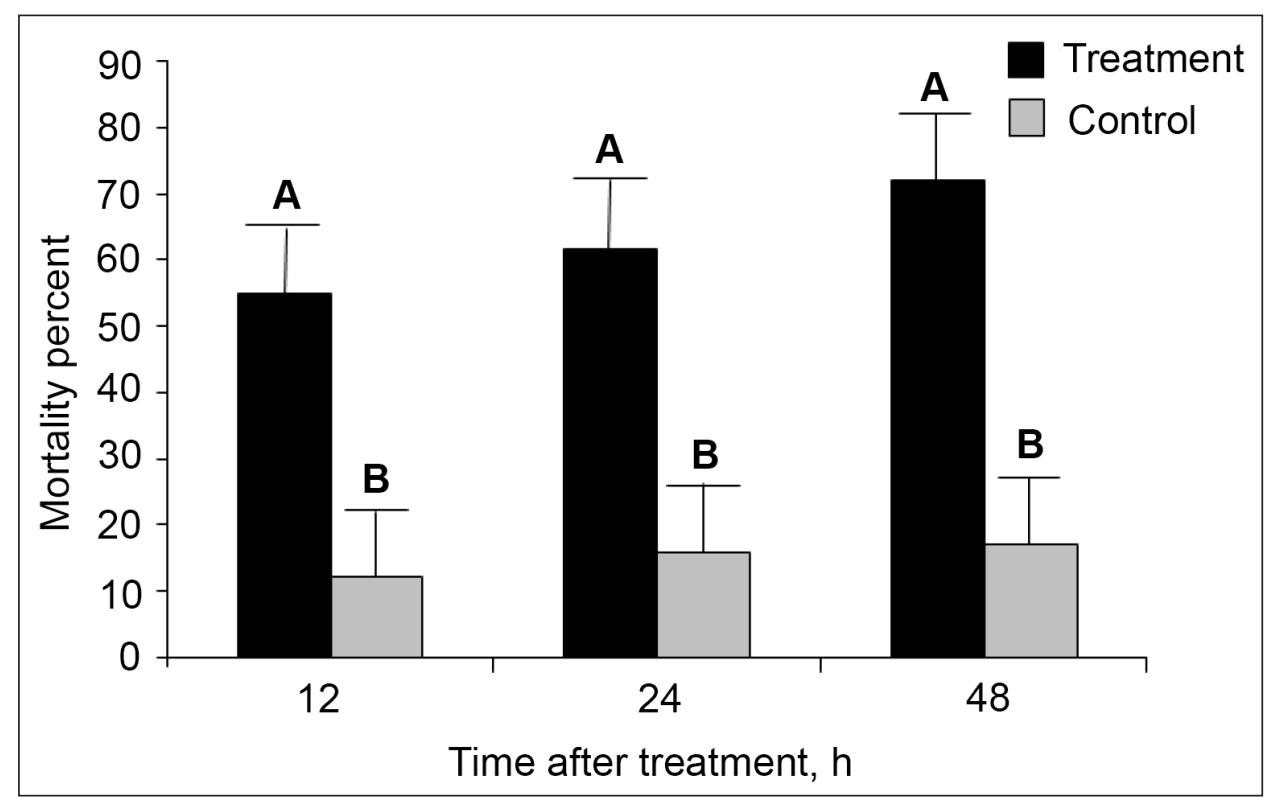

Fig. 1. The mean mortality of Varroa mites 12,24 , and 48 hours after the spraying of thyme ethanol extract

Tukey's test was used to compare the means $(P \leq 0.05)$. There are significant differences between means with different letters. 


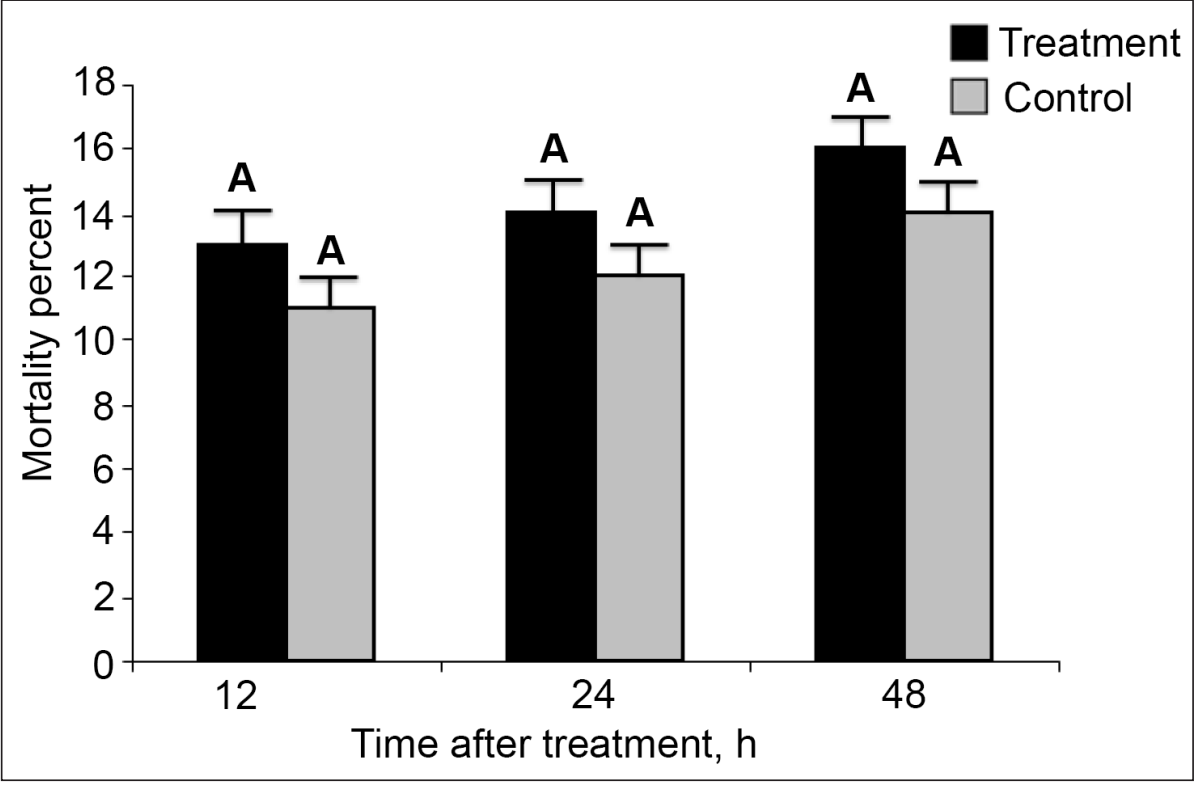

Fig. 2. The mortality of adult honey bees 12, 24, and 48 hours after spraying of thyme ethanol extract on Varroa mites

Different alphabet letters are indicative of a significant difference between different means $(P \leq 0.05)$. Tukey's test was used.

\section{DISCUSSION}

As there were records about the resistance of Varroa mites to chemical acaricides such as Fluvalinate, Coumaphos, Amitraz and Apistan (Martinez et al., 2011; Soumataru et al., 2005; Rodriguez et al., 2005; Martin, 2004; Johnson et al., 2010), the use of plant extracts as acaricides was sought as an alternative. In the past years considerable research has been conducted into the acaricides activity of different plant extracts that have been used to study their effectiveness against Varroa mites and some of these extracts proved to be very effective acaricides. Our present study demonstrates that thyme ethanol extract is highly toxic to Varroa mites and its toxicity will increase by advancement of time from $12 \mathrm{~h}$ to $24 \mathrm{~h}$ and to 48 hours. Compared to honey bees, the $\mathrm{LC}_{50} \%$ of the thyme extract for Varroa mites showed that $\mathrm{LC}_{50}$ values for Varroa mites are lower than those for honey bees. Findings of other researchers show that Varroa mites were more sensitive to different plant extracts and essences than honey bees. Ruffinego et al. (2007) reported that when 500 ppm of essences of two plant species, Tagetes mimuta L. and Heterodera latifolia Buckey, were sprayed on honey bees with Varroa in- festation, it resulted in $70 \%$ mortality of Varroa mites versus $10 \%$ mortality for honey bees 48 hours after spraying. The essence extracted from the oregano (Origanum vulgare) was used to test its efficiency against Varroa mites and the results obtained showed that by the advancement of time from spraying, the percentage of mortality increased both for Varroa mites and for honey bees. The $\mathrm{LC}_{50}$ of the oregano essence $9 \mathrm{~h}$ and $10 \mathrm{~h}$ after application of spray to Varroa mites was 1.65 and $2.05 \mu \mathrm{l} / \mathrm{ml}$, respectively, while for honey bees the values were 4.76 and $5.08 \mu \mathrm{l} / \mathrm{ml}$ for the same lapse of time. It is an indication that Varroa mites were more sensitive to the oregano essence than honey bees (Ghasemi et al., 2010). Our researches on Varroa mites in honey bee hives in field have confirmed the results obtained by Ruffinego et al. (2007) and Ghasemi et al. (2010). Other researchers have found that the bees with bigger body size and body weight, fattier bees, and those with active enzymes that could detoxify the toxic materials entering their bodies were potentially more resistant to any toxic agent than normal bees (Javvi et al., 2005). We have calculated as $12.6 \mu \mathrm{l} / \mathrm{ml}$ the $\mathrm{LC}_{50}$ of thyme leaf extract for Varroa mites, 24 hours after spraying the infested bees. The results obtained from our 
experiments on Varroa mites using thyme leaf ethanol extract showed that this extract could control the Varroa mites efficiently. As thyme has essential oils such as thymol and carvacrol which have proven to be effective as an insecticide and acaricide, so the ethanol extract of its leaves is useful to control Varroa mites (Sertkaya et al., 2010; Szczepanik et al., 2012; Ghasemi et al., 2010). Imdorf et al. (1995) showed that thymol and carvacrol cause high mortality of Varroa mites without having significant negative impacts on honey bees. Collin et al. (1994) showed that spraying the aqueous emulsion of carvacrol on Varroa mites could result in their 90\% mortality 24 hours after spraying.

There are other researchers who have studied the effect of thymol and carvacrol on the tracheal mite of honey bee (Acarapis woodi (Rennie, 1921)). They concluded that these two essences extracted from thyme could inflict high mortality in those mites (Ellis, Baxendale, 1997). In Iran, studies have been conducted to identify the chemical composition of the thyme extract and the results have confirmed that thymol, paracin, beta-caryophylline, and methyl carvacrol were the principal components of thyme (Akbarinia, Mirza, 2008). Compared to our findings, we found that the mortality of Varroa mites begins five hours after the spraying of the thyme extract and reaches its maximum 24 hours after the spraying (Table 2, Fig. 2).

\section{CONCLUSIONS}

Comparing plant-derived acaricides with chemical acaricides used ordinarily, we conclude that the former are less toxic for humans, mammals, and honey bees and have fewer negative effects on environment. Also, because they do not persist in environment and are easy to use, they should replace the chemical pesticides for the control of Varroa mites. We consider that as a plant extract the ethanol extract of thyme leaves has no hazardous effect on humans, honey bees, and environment and could be safely used in apiaries to control Varroa mites.

\section{ACKNOWLEDGEMENTS}

The authors wish to thank Dr. Mahdi Geravandi (Razi University of Kermanshah) for his help in statistical analysis. Thanks to Zagros Bioidea Co., Razi University Incubator, for all the support.

Received 30 October 2016

Accepted 9 April 2017

\section{References}

1. Abou-Shaara HF. Continuous management of Varroa mite in honey bee, Apis mellifera, colonies. Acarina. 2014; 22: 149-56.

2. Akbarinia A, Mirza M. Identification of essential oil components of Thymus daenesis Celak. in field condition in Qazvin. Journal of Qazvin University Of Medical Sciences. 2008; 12: 52-62.

3. Anderson D, Trueman JWH. Varroa jacobsoni (Acari: Varroidae) is more than one species. Exp Appl Acarol. 2000; 24: 165-89.

4. Bowen-Walker P, Gunn A. The effect of the ectoparasitic mite Varroa destructor on adult worker honey bee (Apis mellifera) emergence weights, water, protein, carbohydrate and lipid levels. Entomol Exp Appl. 2001; 101: 207-17.

5. Colin ME, Ciavarella F, Otero-Colina G, Beizunces LP. A method for characterizing the biological activity of essential oil against Varroa jacobsoni. In Matheson, A, editor. New perspectives on Varroa. Cardiff, United Kingdom: International Bee Research Association; 1994. p. 109-114.

6. Dehghani M, Ahamdi K. The effects of bitter Sesame and Harmel (Zygophyllum fabago L.) on nymphs and puparium stages of whiteflies (Hom: Aleurodidae: Trialeurodes vaporarium). Daru hai guiahi Iran. 2012; 2: 239-44.

7. De Jong D, De Jong PH, Goncalves LS. Weight loss and other damage to developing worker honey bees from infestation with Varroa jacobsoni. J. Apic Res 1982; 21: 165-7. 
8. Ellis MD, Baxendale FP. Toxicity of seven monoterpenoids to tracheal mites Acari: Tarsonomidae) and their honey bee (Hymenoptera: Apidae) hosts when applied as fumigants. J Econ Entomol. 1997; 90: 1087-91.

9. Elzen PJ, Eischen FA, Baxter JB, Pettis J, Elzen GW, Wilson WT. Fluvalinate resistance in Varroa jacobsoni from several geographic locations. Am Bee J. 1998; 138: 674-6.

10. Elzen PJ, Baxter JR, Spivak M, Wilson WT. Control of Varroa jacobsoni Oud. Resistant to fluvalinate and amitraz using coumaphos. Apidologie. 2000; 31: 437-41.

11. Georges K, Jayaprakasam B, Dalavoy SS, Nair MG. Pest-managing activities of plant extracts and anthraquinones from Cassia nigricans from Burkina Faso. Biosource Technol. 2007; 99: 2037-45.

12. Ghasemi V, Moharramipour S, Tahmasebi GH. Acaricidal activity of essential oil from Mentha longifolia (Lamiaceae) against Varroa destructor (Acari: Varroidae) and its effect on Apis mellifera (Hym.: Apidae). Journal of the Entomological Society of Iran. 2010; 30: 31-45.

13. IBM SPSS Statistics for Windows, Version 22.0. Armonk, NY: IBM Corp. Released 2013.

14. Imdorf $\mathrm{A}$, Kilchenmann $\mathrm{V}, \mathrm{Bogdanov} \mathrm{S}, \mathrm{Ba}-$ chofen B, Beretta C. Toxic effects of thymol, camphor, menthol and eucalyptol on Varroa jacobsoni Oud and Apis mellifera L. in a laboratory test. Apidologie. 1995; 26: 27-31.

15. Johnson RM, Ellis MD, Mullin CA, Frazier M. Pesticides and honey bee toxicity - USA. Apidologie. 2010; 41: 312-31.

16. Kim HG, Jeon JH, Kim MK, Lee HS. Pharmacological ectsofasaron aldehyde isolated from Acorus grum in Eushizome. Food Sci Biotechnol. 2005 ; 14: 685-8.

17. Levinson $\mathrm{H}$, Levinson A. Control of stored food pests in the ancient orient and classical antiquity. J Appl Entomol. 1998; 22: 127-44.

18. Liu CH, Mishra AK, Tan RX, Tang C, Yang H, Shen YF. Repellent and insecticidal activities of essential oils from Artemisia princeps and Cinnamomum camphora and their effect on seed germination of wheat and broad bean. Biosource Technol. 2005; 97: 1969-73.

19. Martin SJ. Acaricide (pyrethroid) resistance in Varroa destructor. Bee World. 2004; 85: 67-9.

20. Milani N. The resistance of Varroa jacobsoni Oud. to pyrethroids: a laboratory assay. Apidologie. 1995; 26: 415-29.

21. Martinez FJ, Puc LA, Medina M. Evaluation of the resistance of the mite Varroa destructor to the fluvalinate in colonies of honey bees (Apis mellifera) in Yucatan, Mexico. Rev Mex Cienc Pecu. 2011; 2: 93-9.

22. Priestley CM, Williamson EM, Wafford KA, Sattelle DB. Thymol, a constituent of Thyme essential oil, is a positive allosteric modulator of human GABA receptors and a homooligomeric GABA receptor from Drosophila melanogaster. Brit J Pharmacol. 2003; 140: 1363-72.

23. Raja N, Albert S, Ignacimuthu S, Dorn S. Effect of plant volatile oils in protecting stored cowpea Vigna unguiculata (L.) Walpers against Callosobruchus maculates (F.) (Coleoptera: Bruchidae) infestation. J Stored Prod Res. 2001; 37: 127-32.

24. Rahimi A, Mirmoayedi A, Khanjani M. Dispersion type of Varroa mite (Acari, Varroidae) Among the Bee hives in Kurdistan Province, Iran. International Journal of Farming and Allied Sciences. 2014; 3: 255-9.

25. Ranjabar-Bahadori S, Farhadifar N, Mohammadyar L. Assessment of susceptibility of the Poultry Red Mite, Dermanyssus gallinae (Acari: Dermanyssidae) to some plant preparations with focus on exposure time. International Journal of Biological, Biomolecular, Agricultural, Food and Biotechnological Engineering. 2014; 8: 573-6.

26. Reed DK, Warthen JR, Uebel EC, Reed GL. Effects of two triperpenoids from neem on feeding by cucumber beetles (Coleoptera: Chrysomelidae). J Econ Entomol. 1982; 75: 1109-13. 
27. Rodríguez-Dehaibes SR, Otero-Colina G, Pardio Sedas V, Villaneuva Jiménez VA. Resistance to Amitraz and Flumethrin in Varroa destructor populations from Veracruz. Mex J Apicult. Res. 2005; 44: 68-9.

28. Ruffinengo S, Eguaras M, Bailac P, Torres J, BaSualdo M, Ponzi M. Essential oils in the control of Varroa destructor. An evaluation in laboratory conditions. Proceedings of the 37 th International Apicultural Congress, 28 Oct - 1 Nov 2001, Durban, South Africa.

29. Ruffinengo SR, Eguaras MJ, Floris I, Faverín C, Bailac PN, Ponzi MI. LD50 and repellent effects of essential oils from Argentinian wild plant species on Varroa destructor. J Econ Entomol. 2005; 98: 651-5.

30. Sertkaya E, Kaya K, Solu S. Acaricidal activities of the essential oils from several medicinal plants against the carmine spider mite (Tetranychus cinnabarinus Boisd.) (Acarina: Tetranychidae). Ind Crop Prod. 2010; 31: 107-12.

31. Sammataro D, Untalan P, Guerrero F, Finley J. The resistance of Varroa mites (Acari: Varroidae) to acaricides and the presence of esterase. Internat J Acarol. 2005; 31: 67-74.

32. Szczepanik M, Zawitowska B, Szumny A. Insecticidal activities of Thymus vulgaris essential oil and its components (Thymol and Carvacrol) against larvae of lesser mealworm, Alphitobius diaperinus Panzer (Coleoptera: Tenebrionidae). Allelopathy J. 2012; 30: 129142.

33. StatPlus. For Windows. Version 4.9, Analyst Soft Inc. 2007, USA.

34. Ventura MU, Ito M. Antifeedant activity of Melia azedarach (L.) extracts to Diabrotica speciosa (Genn.) (Coleoptera: Chrysomelidae) beetles. Brazilian Archives of Biology and Technology. 2000; 43: 215-9.

35. Wandscheer CB, Duque JE, Da Silva M, Fukuyama Y, Wohlke JL, Adelmann J, Fontana JD. Larvicidal action of ethanol extracts from fruit endocarps of Melia azedarach and Azadirachta indica against the dengue mosquito Aedes aegypti. Toxicon. 2004; 44: 829-35.
36. Yazdani E, Jalali Sendi J, Hajizadeh J. Effect of Thymus vulgaris L. and Origanum vulgare L. essential oils on toxicity, food consumption, and biochemical properties of lesser mulberry pyralid Glyphodes pyloalis Walker (Lepidoptera: Pyralidae). Journal of Plant Protection Research. 2014; 54: 53-61.

\section{Ataollah Rahimi, Yaser Khoram Del, Farzad Moradpour}

\section{ČIOBRELIO (THYMUS CAUCASICUS) ETA- NOLINIO EKSTRAKTO POVEIKIS VAROA- TOZĖS ERKĖMS (VARROA DESTRUCTOR), PARAZITUOJANČIOMS BITES (APIS MELLI- FERA MEDA)}

\section{Santrauka}

Varoatozès erkių (Varroa destructor), vieno svarbiausių naminių bičių kenkèjų, cheminè kontrolè yra praktikuojama visame pasaulyje, tačiau, naudojant daugybę skirtingų miticidų, daugeliui jų erkès tapo atsparios. Šio tyrimo metu naminių bičių varoatozès erkių kontrolei buvo pasirinkta nesintetinè cheminè medžiaga - čiobrelio (Thymus caucasicus) etanolinis ekstraktas. Laukiniai čiobreliai buvo surinkti 2013 m. rugsèjo - spalio mėnesiais Kurdistano kalnuose. Čiobrelių ekstraktas pagamintas naudojant $95 \%$ etilo alkoholi. Atsitiktine tvarka sukomplektuotą statistini modelį sudarè 10 skirtingų čiobrelio etanolinio ekstrakto koncentracijų ir viena kontrolè su grynu $95 \%$ etanoliu. Šeimos avilio vidinè temperatūra buvo $30 \pm 1{ }^{\circ} \mathrm{C}$, o aplinkos $-33 \pm 2{ }^{\circ} \mathrm{C}$. Čiobrelio ekstraktas ant bičių buvo purškiamas kas 12, 24 ir 48 valandas. Iš kiekvieno avilio apatinès plokštès ištrauktos negyvos erkès buvo suskaičiuojamos. Tyrimo rezultatai rodo, kad naudojant čiobrelio ekstraktą erkių mirtingumo procentas gerokai skyrèsi, palyginti su kontrole. Bičių mirtingumo procentas kontroliniuose aviliuose ir aviliuose, kurie buvo purškiami čiobrelio etanoliniu ekstraktu, reikšmingai nesiskyrè. Eksperimento išvada: čiobrelio etanolinio ekstrakto naudojimas aviliuose buvo saugus, be didesnès bičių mirtingumo rizikos.

Raktažodžiai: naminè bité, Iranas, Kurdistano provincija, čiobrelio ekstraktas, varoatozès erkè 